$0-414$

J. Chem. Thermodynamics 1991, 23, 653-665

\title{
Thermodynamic properties of ammonium haloplatinates
}

\section{Heat capacity and thermodynamic functions of deuterated ammonium hexachloroplatinate $\left(\mathrm{ND}_{4}\right)_{2} \mathrm{PtCl}_{6}$ at temperatures from $5 \mathrm{~K}$ to $350 \mathrm{~K}$}

\author{
RON D. WEIR ${ }^{a}$ \\ Department of Chemistry and Chemical Engineering, \\ Royal Military College of Canada, \\ Kingston, Ontario K7K 5LO, Canada \\ and EDGAR F. WESTRUM, JR. \\ Department of Chemistry, University of Michigan, \\ Ann Arbor, MI 48109-1055, U.S.A.
}

(Received 16 November 1990)

\begin{abstract}
The heat capacity of deuterated ammonium hexachloroplatinate $\left(\mathrm{ND}_{4}\right)_{2} \mathrm{PtCl}_{6}$ was measured at temperatures from $5 \mathrm{~K}$ to $350 \mathrm{~K}$ by adiabatic calorimetry. One $\lambda$-shaped anomaly, absent in the undeuterated salt, was found in the curve for heat capacity against temperature. This $\lambda$-shaped transition reaches its maximum $C_{p, \mathrm{~m}} \approx 59.3 \cdot R$ at $(27.2 \pm 0.05) \mathrm{K}$ with $\Delta_{\mathrm{trs}} S_{\mathrm{m}}^{\circ}=$ $(1.216 \pm 0.004) \cdot R$, characteristic of an order-disorder transition. Smoothed values of the standard thermodynamic quantities for pure $\left(\mathrm{ND}_{4}\right)_{2} \mathrm{PtCl}_{6}$ are tabulated at temperatures up to $350 \mathrm{~K}$.
\end{abstract}

\section{Introduction}

The hexahalogenated metal salts in the family $\mathrm{A}_{2} \mathrm{MX}_{6}(\mathrm{~A}=$ an alkali metal, $M=$ transition metal or polyvalent ion, and $X=$ a halogen) normally crystallize at room temperature into the cubic antifluorite structure with space group $\mathrm{Fm} 3 \mathrm{~m}$ or No. $225 O_{h}^{5}$. Some compounds in this family experience structural phase transitions as the temperature is lowered, thereby changing into a phase of lower symmetry. However, other members of the family exhibit no sign of a transition. ${ }^{(1,2)}$ An empirical geometrical model ${ }^{(3)}$ has been developed to account for the stability of those crystals whose phase transitions correspond to distortions of the unit cell. The model is based on the experimental finding that as the cation size increases and that

${ }^{a}$ To whom correspondence should be sent. 
of halogen ligand decreases, the transition temperatures are shifted to lower values. It is also known that the transition temperatures depend on the d-electron configuration of the metal atom. ${ }^{(1)}$ For some salts in this family, the transitions are accompanied by distortions of the cubic lattice but without a coupling to the octahedral rotations, while in other salts the transitions involve only small angle librations of the $\mathrm{MX}_{6}^{2-}$ octahedra. ${ }^{(1,2,4)}$ For both $\mathrm{K}_{2} \mathrm{ReCl}_{6}$ and $\mathrm{K}_{2} \mathrm{OsCl}_{6}$, the transitions from cubic to tetragonal structures are displacive transitions caused by the softening of the rotary lattice modes. ${ }^{(5-7)}$

The replacement of the alkali metal by either $\mathrm{NH}_{4}^{+}$or $\mathrm{ND}_{4}^{+}$results in additional librational degrees of freedom. In addition in these $\left(\mathrm{NH}_{4}\right)_{2} \mathrm{MX}_{6}$ salts, the structural phase transition of the alkali-metal analogue is either lowered by the tetrahedral symmetry of the ammonium ion or suppressed entirely. ${ }^{(4)}$ The presence of the polyatomic anion with the distribution of charge over the large area of atoms weakens the electrostatic attraction between any of these atoms and a hydrogen of an ammonium ion. This in turn leads to a low barrier for rotation of either $\mathrm{NH}_{4}^{+}$or $\mathrm{ND}_{4}^{+}$.

The stable cubic phase ${ }^{(8)}$ of undeuterated ammonium hexafluorosilicate $\left(\mathrm{NH}_{4}\right)_{2} \mathrm{SiF}_{6}$ exhibits no transition in its crystal structure below room temperature and heat-capacity measurements show no anomaly down to $25 \mathrm{~K} .{ }^{(9)}$ The barrier to rotation of the $\mathrm{NH}_{4}^{+}$is $1616 \mathrm{~K}$ based on heat capacities, ${ }^{(10)}$ but $1107 \mathrm{~K}$ from n.m.r. results. ${ }^{(11)}$ Heat-capacity measurements show no anomaly in the deuterated analogue $\left(\mathrm{ND}_{4}\right)_{2} \mathrm{SiF}_{6}$ over the temperature range $6 \leqslant T / \mathrm{K} \leqslant 343$, and they yield a librational wavenumber for the $\mathrm{ND}_{4}^{+}$of $122 \mathrm{~cm}^{-1} .^{(12)}$ Similarly the cubic $\left(\mathrm{NH}_{4}\right)_{2} \mathrm{SnCl}_{6}$ is also without a phase transition between $300 \mathrm{~K}$ and $20 \mathrm{~K}$, but the barrier to $\mathrm{NH}_{4}^{+}$rotation is much lower at $740 \mathrm{~K}$ to $600 \mathrm{~K} .^{(10,11,14-16)}$ However, the deuterated salt $\left(\mathrm{ND}_{4}\right)_{2} \mathrm{SnCl}_{6}$ undergoes a transition around $244 \mathrm{~K}$ manifested as a $\lambda$-shaped anomaly in the heat capacity. ${ }^{(17)}$ Whether its high-temperature cubic structure changes as the temperature is lowered below $244 \mathrm{~K}$ is not known, but the low-temperature structure is currently under study by Powell and Weir.

The barrier to $\mathrm{NH}_{4}^{+}$rotation in $\left(\mathrm{NH}_{4}\right)_{2} \mathrm{PtCl}_{6}$ is even lower at $342 \mathrm{~K},{ }^{(16)}$ which has spawned work to determine the rotational potential of $\mathrm{NH}_{4}^{+}$in this compound ${ }^{(18,19)}$ and in related ammonium hexachlorides. ${ }^{(20)}$ Recent heat-capacity measurements by adiabatic calorimetry show neither transitions nor anomalies from $6 \mathrm{~K}$ to $348 \mathrm{~K}$, ${ }^{(21)}$ making this salt an ideal candidate for examining rotational motion of the $\mathrm{NH}_{4}^{+}$. A knowledge of the heat capacity of the deuterated analogue should also help in understanding the mechanism of molecular rotation of the ammonium ion. At $300 \mathrm{~K}$, both salts have an antifluorite-like structure with space group $\mathrm{Fm} 3 \mathrm{~m}$ (No. $225 \mathrm{O}_{h}^{5}$ ) and four formula units in the face-centred cell. ${ }^{(22,23)}$ Each ammonium ion is coordinated with 12 equivalent $\mathrm{Cl}^{-}$atoms at the corners of the unit cell and the hydrogen atoms within the $\mathrm{NH}_{4}^{+}$or $\mathrm{ND}_{4}^{+}$point towards empty corners as shown in figure 1 of reference 21 . Rotation of the $\mathrm{NH}_{4}^{+}$or $\mathrm{ND}_{4}^{+}$is indicated around both a twofold and a threefold axis. The absence of published heat-capacity measurements for $\left(\mathrm{ND}_{4}\right)_{2} \mathrm{PtCl}_{6}$ has led us to determine these at temperatures from $5 \mathrm{~K}$ to $350 \mathrm{~K}$ by adiabatic calorimetry as part of our programme of study involving ammonium salts. 


\section{Experimental}

The sample of $\left(\mathrm{ND}_{4}\right)_{2} \mathrm{PtCl}_{6}$ was prepared from $\left(\mathrm{NH}_{4}\right)_{2} \mathrm{PtCl}_{6}$ which was supplied by the Aldrich Chemical Company as 99.999 mass per cent pure according to the Certificate of Analysis. No other elements were detected by spectrographic trace analysis at the detection level of mass fraction $1 \times 10^{-6}$. The Guinier-de Wolff diffraction pattern of the $\left(\mathrm{NH}_{4}\right)_{2} \mathrm{PtCl}_{6}$ was in perfect agreement with the standard pattern for this compound ${ }^{(21)}$ and showed no traces of $\mathrm{NH}_{4} \mathrm{Cl}$. About $12 \mathrm{~g}$ was dissolved in $1300 \mathrm{~cm}^{3}$ of $\mathrm{D}_{2} \mathrm{O}$ (at least 99.8 moles per cent nuclidic purity) contained in a Pyrex beaker. To ensure complete dissolution, the yellow-orange mixture was warmed to $353 \mathrm{~K}$. Upon recrystallization, a partially deuterated product was obtained. This procedure, carried out in a dry atmosphere, was repeated twice, whereupon the crystalline $\left(\mathrm{ND}_{4}\right)_{2} \mathrm{PtCl}_{6}$ product had a mass of $10.2 \mathrm{~g}$. To remove most of the $\mathrm{D}_{2} \mathrm{O}$ trapped as fluid inclusions in the crystals of $\left(\mathrm{ND}_{4}\right)_{2} \mathrm{PtCl}_{6}$ upon recrystallization, the salt was dried at atmospheric pressure within the dry box, where the sample was maintained at temperatures up to $313 \mathrm{~K}$ for $14 \mathrm{~d}$ with an infrared lamp. A t.g.a. was done on $10 \mathrm{mg}$ to $20 \mathrm{mg}$ samples removed at intervals.

The Guinier-de Wolff diffraction pattern of our sample was in agreement with the standard pattern for this compound: No. 7-218 as determined by the Joint Committee for Powder Diffraction Standards. ${ }^{(22)}$ Its structure is face-centred cubic at room temperature with $a=(0.9856 \pm 0.0001) \mathrm{nm}$. Some scattering from a small amount of $\mathrm{ND}_{4} \mathrm{Cl}$ impurity was noted.

As a check for $\mathrm{D}_{2} \mathrm{O}$ trapped within our 'dried' sample of $\left(\mathrm{ND}_{4}\right)_{2} \mathrm{PtCl}_{6}$, the final t.g.a. was done on an $11 \mathrm{mg}$ portion of the sample which was to be loaded subsequently into the calorimeter. On heating to $400 \mathrm{~K}$, a mass loss of 0.18 per cent occurred, some of which was thought to be due to decomposed sample. The amount of $\mathrm{D}_{2} \mathrm{O}$ present was expected to be lowered on loading the calorimeter, at which time the sample was vacuum pumped. A platinum resistance thermometer was used in the t.g.a. instrument to measure temperature and was calibrated at the ice point and the fixed points of the Curie transition in alumel at $422.5 \mathrm{~K}$, in nickel at $631.2 \mathrm{~K}$, and in Traflperm ( 97 mass per cent of $\mathrm{Fe}+3$ mass per cent of Si) at $1018.8 \mathrm{~K}$. The estimated precisions were $\pm 2 \mathrm{~K}$ and $\pm 1 \times 10^{-6} \mathrm{~g}$.

The molar heat capacity $C_{p, \mathrm{~m}}$ of the sample was measured at temperatures from $5 \mathrm{~K}$ to $350 \mathrm{~K}$ in the Mark XIII adiabatic cryostat, which is an upgraded version of the Mark II cryostat described previously. ${ }^{(24)} \mathrm{A}$ guard shield was incorporated to surround the adiabatic shield. A Leeds and Northrup capsule-type platinum resistance thermometer (laboratory designation A-5) was used for temperature measurements. The thermometer was calibrated at the U.S. National Bureau of Standards (N.B.S.) against the IPTS-48 (as revised in 1960) ${ }^{(25)}$ for temperatures above $90 \mathrm{~K}$, against the N.B.S. provisional scale from $10 \mathrm{~K}$ to $90 \mathrm{~K}$, and by the technique of McCrackin and Chang ${ }^{(26)}$ below $10 \mathrm{~K}$. These calibrations are judged to reproduce thermodynamic temperatures to within $0.03 \mathrm{~K}$, between $10 \mathrm{~K}$ and $90 \mathrm{~K}$ and within $0.04 \mathrm{~K}$ above $90 \mathrm{~K}^{(27)}$ Measurements of mass, current, potential difference, and time were based upon calibrations done at N.B.S. The acquisition of heat capacities was assisted ${ }^{(28,29)}$ by a computer programmed for a series of 
determinations. During the drift periods, both the calorimeter temperature and its first and second derivatives of temperature with respect to time were recorded to establish the equilibrium temperatures of the calorimeter between the energy inputs. During energy inputs, the heater current and potential and the duration of the heating interval were obtained. Also recorded were the apparent heat capacity of the system including the calorimeter, heater, thermometer, and sample.

A gold-plated copper calorimeter (laboratory designation W-99) with four internal vertical vanes and a central entrant well for (heater + thermometer) was loaded with $\left(\mathrm{ND}_{4}\right)_{2} \mathrm{PtCl}_{6}$. After loading, the calorimeter was evacuated and pumping was continued for several hours to ensure that moisture was no longer released from the sample. After addition up to a pressure of about $2.4 \mathrm{kPa}$ (at $300 \mathrm{~K}$ ) of helium gas to the vessel to facilitate thermal equilibration, it was then sealed by means of an annealed gold gasket tightly pressed on to the stainless-steel knife edge of the calorimeter top with a screw closure about $5 \mathrm{~mm}$ in diameter.

Buoyancy corrections were calculated on the basis of a crystallographic density of $3.127 \mathrm{~g} \cdot \mathrm{cm}^{-3}$ derived from the unit cell edge of our sample. The mass of $\left(\mathrm{ND}_{4}\right)_{2} \mathrm{PtCl}_{6}$ amounted to $10.1819 \mathrm{~g}$ (气0.0225296 mol based on its molar mass of $451.9334 \mathrm{~g} \cdot \mathrm{mol}^{-1}$ from IUPAC 1983 atomic masses).

The thermal history of the $\left(\mathrm{ND}_{4}\right)_{2} \mathrm{PtCl}_{6}$ is represented by the following linear array. The arrows denote either cooling or heating, which correspond to the acquisition of heat-capacity results.

$$
\begin{aligned}
& 300 \mathrm{~K} \stackrel{14 \mathrm{~h}}{\longrightarrow} 58 \mathrm{~K} \stackrel{4 \mathrm{~h}}{\longrightarrow} 5 \mathrm{~K} \underset{\text { Series I }}{\stackrel{3 \mathrm{~h}}{\longrightarrow}} 20 \mathrm{~K} \underset{\text { Series II }}{\stackrel{7 \mathrm{~h}}{\longrightarrow}} 77 \mathrm{~K} \\
& \stackrel{4 \mathrm{~h}}{\longrightarrow} 15 \mathrm{~K} \underset{\text { Series III }}{\stackrel{6 \mathrm{~h}}{\longrightarrow}} 38 \mathrm{~K} \stackrel{2 \mathrm{~h}}{\longrightarrow} 16 \mathrm{~K} \underset{\text { SeriesIV }}{\stackrel{2 \mathrm{~h}}{\longrightarrow}} 77 \mathrm{~K} \\
& \stackrel{10 \mathrm{~h}}{\longrightarrow} 240 \mathrm{~K} \underset{\text { Series VI }}{\stackrel{6 \mathrm{~h}}{\longrightarrow}} 350 \mathrm{~K} \stackrel{6 \mathrm{~h}}{\longrightarrow} 227 \mathrm{~K} \underset{\text { Series VII }}{\stackrel{9 \mathrm{~h}}{\longrightarrow}} 325 \mathrm{~K} \\
& \stackrel{10 \mathrm{~h}}{\longrightarrow} 225 \mathrm{~K} \underset{\text { Series VIII }}{\stackrel{9 \mathrm{~h}}{\longrightarrow}} 309 \mathrm{~K}
\end{aligned}
$$

\section{Results and discussion}

The experimental molar heat capacities for $\left(\mathrm{ND}_{4}\right)_{2} \mathrm{PtCl}_{6}$ are presented in table 1 . Except for points in the region of the anomalies, the standard errors in our heatcapacity values decrease from about 1 per cent at $10 \mathrm{~K}$ to less than 0.15 ,per cent at temperatures above $30 \mathrm{~K}$. The heat capacity of the sample represented about 0.45 to 0.60 of the measured total heat capacity away from the region of the anomalies.

Special care was taken with respect to particle size and thermal history of our $\left(\mathrm{ND}_{4}\right)_{2} \mathrm{PtCl}_{6}$ sample in view of the hysteresis in heat capacity found in other ammonium compounds, although no difficulty was experienced by us with $\left(\mathrm{NH}_{4}\right)_{2} \mathrm{PtCl}_{6}{ }^{\left({ }^{(21)}\right.}$ However, reproducibilities of heat-capacity results for $\mathrm{NH}_{4} \mathrm{PF}_{6}$, $\mathrm{RbPF}_{6},\left(\mathrm{NH}_{4}\right)_{2} \mathrm{SnCl}_{6}, \mathrm{~K}_{2} \mathrm{SnCl}_{6}$, and $\mathrm{Rb}_{2} \mathrm{SnCl}_{6}$ were all dependent on particle size, 
TABLE 1. Experimental molar heat capacity of $\left(\mathrm{ND}_{4}\right)_{2} \mathrm{PtCl}_{6} \quad\left(M=451.9334 \mathrm{~g} \cdot \mathrm{mol}^{-1}\right.$; $\left.R=8.31451 \mathbf{J} \cdot \mathrm{K}^{-1} \cdot \mathrm{mol}^{-1}\right)$

\begin{tabular}{|c|c|c|c|c|c|c|c|}
\hline$T / \mathrm{K}$ & $C_{p, \mathrm{~m}} / R$ & $T / \mathrm{K}$ & $C_{p, \mathbf{m}} / R$ & $T / \mathrm{K}$ & $C_{p, \mathrm{~m}} / R$ & $T / \mathrm{K}$ & $C_{p, \mathbf{m}} / R$ \\
\hline \multicolumn{2}{|c|}{ Series I } & 25.42 & 6.415 & 203.74 & 30.34 & 296.34 & 33.39 \\
\hline 5.60 & 0.0648 & 26.31 & 7.776 & 210.44 & 30.59 & 299.76 & 33.52 \\
\hline 6.72 & 0.1160 & 26.93 & 22.13 & 217.14 & 30.93 & 303.19 & 33.65 \\
\hline 8.43 & 0.2828 & 27.16 & 59.27 & 223.83 & 31.36 & 306.62 & 33.85 \\
\hline 9.44 & 0.4025 & 27.29 & 51.02 & 230.51 & 31.84 & 310.04 & 33.99 \\
\hline 10.45 & 0.5414 & 27.61 & 13.61 & 237.18 & 32.46 & 313.46 & 34.15 \\
\hline 11.40 & 0.6905 & 28.37 & 6.403 & \multicolumn{2}{|c|}{ Series VI } & 316.89 & 34.29 \\
\hline 12.45 & 0.8698 & 29.40 & 6.210 & \multicolumn{2}{|c|}{$\Delta_{\mathrm{trs}} H_{\mathrm{m}}$ Detn. } & 320.31 & 34.42 \\
\hline 13.54 & 1.097 & 30.38 & 6.441 & 256.80 & 32.36 & 323.74 & 34.56 \\
\hline 14.63 & 1.340 & 31.54 & 6.762 & 269.84 & 32.83 & Serie & VIII \\
\hline 15.73 & 1.638 & 32.62 & 7.026 & 276.36 & 35.62 & $\Delta_{\mathrm{tra}} H_{\mathrm{n}}$ & Detn. \\
\hline 16.92 & 2.005 & 33.64 & 7.286 & 283.07 & 33.44 & 226.24 & 31.52 \\
\hline 18.19 & 2.443 & 34.60 & 7.572 & 289.85 & 33.27 & 229.74 & 31.76 \\
\hline 19.49 & 2.890 & 35.52 & 7.793 & 296.52 & 33.38 & 233.87 & 32.08 \\
\hline \multicolumn{2}{|c|}{ Series II } & 36.31 & 8.016 & 303.15 & 33.72 & 238.01 & 32.52 \\
\hline 19.15 & 2.758 & 37.07 & 8.223 & 309.77 & 33.96 & 242.15 & 33.02 \\
\hline 20.56 & 3.202 & 37.78 & 8.449 & 316.39 & 34.29 & 246.26 & 33.66 \\
\hline 21.90 & 3.683 & \multicolumn{2}{|c|}{ Series IV } & 323.01 & 34.54 & 249.26 & 35.45 \\
\hline 23.35 & 4.268 & \multicolumn{2}{|c|}{$\Delta_{\mathrm{trs}} H_{\mathrm{m}}$ Detn. } & 329.63 & 34.78 & 251.15 & 37.20 \\
\hline 25.18 & 6.414 & \multicolumn{2}{|c|}{ Series V } & 336.25 & 35.07 & 253.02 & 34.46 \\
\hline 26.67 & 16.77 & \multicolumn{2}{|c|}{$\Delta_{\mathrm{trs}} H_{\mathrm{m}}$ Detn. } & 342.98 & 35.30 & 254.98 & 32.95 \\
\hline 27.88 & 18.94 & 78.73 & 18.58 & 348.21 & 35.51 & 256.97 & 32.35 \\
\hline 30.58 & 6.461 & 82.60 & 19.38 & \multicolumn{2}{|c|}{ Series VII } & 258.97 & 32.38 \\
\hline 33.31 & 7.205 & 86.69 & 20.19 & \multicolumn{2}{|c|}{$\Delta_{\mathrm{trs}} H_{\mathrm{m}}$ Detn. } & 260.98 & 32.41 \\
\hline 34.99 & 7.634 & 91.02 & 20.90 & 229.15 & 31.72 & 262.98 & 32.43 \\
\hline 36.71 & 8.123 & 95.58 & 21.65 & 232.52 & 31.95 & 264.97 & 32.56 \\
\hline 38.43 & 8.611 & 100.37 & 22.34 & 235.95 & 32.19 & 266.95 & 32.62 \\
\hline 40.35 & 9.097 & 105.34 & 23.03 & 239.38 & 32.67 & 268.93 & 32.75 \\
\hline 42.46 & 9.688 & 110.39 & 23.70 & 242.78 & 33.10 & 270.91 & 32.93 \\
\hline 44.57 & 10.26 & 115.45 & 24.28 & 246.20 & 33.62 & 272.90 & 33.14 \\
\hline 46.69 & 10.86 & 120.53 & 24.83 & 249.56 & 35.80 & 274.87 & 33.37 \\
\hline 48.91 & 11.43 & 125.61 & 25.33 & 252.94 & 34.70 & 276.79 & 35.83 \\
\hline 51.28 & 12.14 & 130.95 & 25.86 & 255.83 & 32.37 & 278.70 & 34.35 \\
\hline 53.78 & 12.73 & 136.55 & 26.38 & 258.70 & 32.38 & 280.63 & 33.59 \\
\hline 56.39 & 13.46 & 142.15 & 26.87 & 262.14 & 32.44 & 284.54 & 33.33 \\
\hline 59.14 & 14.16 & 147.77 & 27.33 & 265.54 & 32.56 & 286.49 & 33.27 \\
\hline 62.03 & 14.85 & 153.39 & 27.71 & 268.94 & 32.76 & 288.82 & 33.26 \\
\hline 65.06 & 15.63 & 159.28 & 28.12 & 272.37 & 33.07 & 291.54 & 33.29 \\
\hline 68.26 & 16.36 & 165.45 & 28.49 & 275.75 & 34.92 & 294.24 & 33.34 \\
\hline 71.62 & 17.12 & 171.62 & 28.79 & 279.14 & 34.23 & 296.93 & 33.42 \\
\hline 75.16 & 17.83 & 177.78 & 29.14 & 282.61 & 33.45 & 299.63 & 33.53 \\
\hline \multicolumn{2}{|c|}{ Series III } & 183.95 & 29.46 & 286.08 & 33.29 & 302.30 & 33.64 \\
\hline 18.86 & 2.681 & 190.37 & 29.75 & 289.50 & 33.27 & 304.99 & 33.63 \\
\hline 22.47 & 3.839 & 197.05 & 30.09 & 292.92 & 33.30 & 307.67 & 33.92 \\
\hline 24.12 & 4.776 & & & & & & \\
\hline
\end{tabular}

which in turn was affected by thermal history. ${ }^{(30,31)} \mathrm{A}$ similar result was found in an n.m.r. study of $\mathrm{KPF}_{6}$ and $\mathrm{RbPF}_{6}{ }^{(32)}$ Our sample of $\left(\mathrm{ND}_{4}\right)_{2} \mathrm{PtCl}_{6}$ was ground to fine particles before it was loaded into the calorimeter and it was then cooled directly from $300 \mathrm{~K}$ to $5 \mathrm{~K}$ in $18 \mathrm{~h}$ when the measurements began. No differences are apparent between the heat-capacity values in our eight series of runs. 


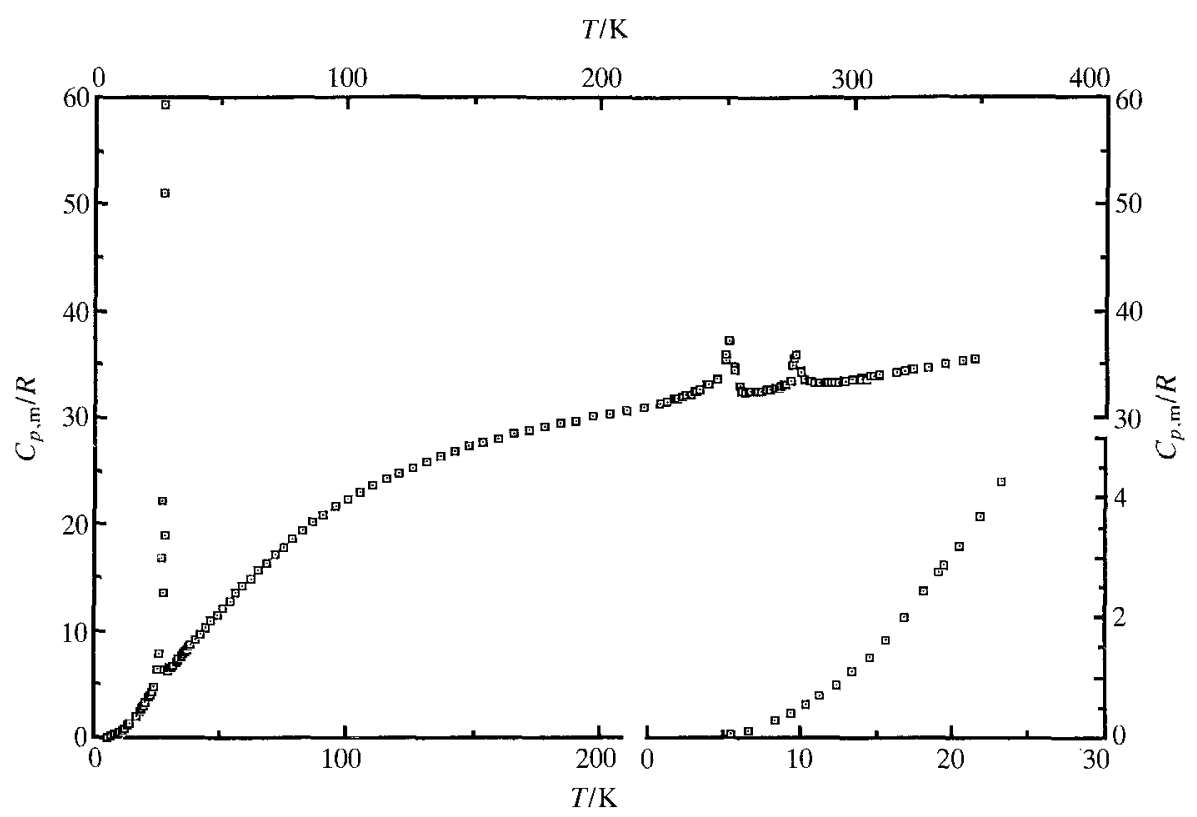

FIGURE 1. Experimental molar heat capacities at constant pressure plotted against temperature $T$ for $\left(\mathrm{ND}_{4}\right)_{2} \mathrm{PtCl}_{6}$ containing impurities 0.07 mass per cent of $\mathrm{D}_{2} \mathrm{O}$ and 0.25 mass per cent of $\mathrm{ND}_{4} \mathrm{Cl}$. The region below $25 \mathrm{~K}$ is enlarged in the lower right-hand corner.

A plot of experimental values of $C_{p, \mathrm{~m}} / R$ against $T$ from $5.6 \mathrm{~K}$ to $348 \mathrm{~K}$ is shown in figure 1 , where three anomalies are evident. One $\lambda$-shaped transition peaks with very high values around $27 \mathrm{~K}$, and two smaller anomalies reach their maxima near $251 \mathrm{~K}$ and $277 \mathrm{~K}$. By carrying out our heat-capacity measurements with sufficiently short heating intervals, the temperature where each heat capacity reaches the maximum was found to be $(27.2 \pm 0.05) \mathrm{K},(251.1 \pm 0.1) \mathrm{K}$, and $(276.8 \pm 0.1) \mathrm{K}$ for these three anomalies, respectively. Three passes were made through the region of the $\lambda$-shaped transition at $27 \mathrm{~K}$ (see the thermal history above: Series II, III, and IV), and reproducible heat capacities resulted. The details of the peak are shown in figure 2. The reproducibility of our measurements of the enthalpy and entropy changes through this region is presented in table 2.

The anomaly centred about $251.1 \mathrm{~K}$ and shown in detail in figure 3 corresponds to the phase transition in the $\mathrm{ND}_{4} \mathrm{Cl}$ impurity, which reaches its peak in the pure salt around $250 \mathrm{~K} .{ }^{(33,34)}$ The Guinier-de Wolff diffraction pattern confirmed the presence of $\mathrm{ND}_{4} \mathrm{Cl}$ in our deuterated sample at $300 \mathrm{~K}$. The impurity formed during the deuteration process, a phenomenon that we have occasionally experienced in other deuteration reactions. Three passes in four different series V to VIII were made through this anomaly to find the associated enthalpy. By interpolating the background heat-capacity curve from about $210 \mathrm{~K}$ to $260 \mathrm{~K}$, the excess enthalpy and entropy associated with the anomaly were determined, which led to the calculation of the $\mathrm{ND}_{4} \mathrm{Cl}$ impurity of 0.25 mass per cent. ${ }^{(33,35)}$ The experimental $C_{p, \mathrm{~m}} / R$ values 


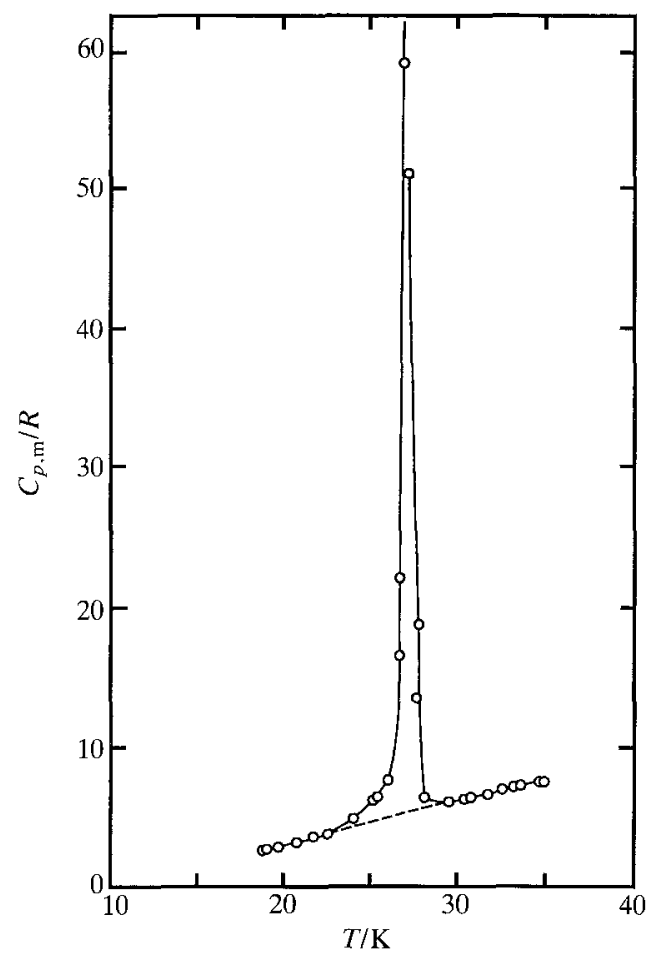

FIGURE 2. Experimental molar heat capacities $C_{p, \mathrm{~m}}$ at constant pressure plotted against temperature $T$ through the region of the $\lambda$-shaped transition from $18 \mathrm{~K}$ to $35 \mathrm{~K}$ for $\left(\mathrm{ND}_{4}\right)_{2} \mathrm{PtCl}_{6} ;-\cdots-$, the lattice curve.

for the $\left(\mathrm{ND}_{4}\right)_{2} \mathrm{PtCl}_{6}$ sample given in table 1 were not adjusted for the $\mathrm{ND}_{4} \mathrm{Cl}$ impurity.

The small peak at the highest temperature around $277 \mathrm{~K}$ corresponds to fusion of the saturated $\mathrm{D}_{2} \mathrm{O}$ salt solution trapped as inclusions in the crystals of $\left(\mathrm{ND}_{4}\right)_{2} \mathrm{PtCl}_{6}$. The normal melting temperature of pure $\mathrm{D}_{2} \mathrm{O}$ is about $276.27 \mathrm{~K}^{(36)}$ Three passes

TABLE 2. Summary of the thermophysical quantities through the $\lambda$-shaped transition at $27.2 \mathrm{~K}$ for $\left(\mathrm{ND}_{4}\right)_{2} \mathrm{PtCl}_{6}\left(R=8.31451 \mathrm{~J} \cdot \mathrm{K}^{-1} \cdot \mathrm{mol}^{-1}\right) . T_{1}$ and $T_{2}$ denote the beginning and ending temperatures, respectively, for three enthalpy determinations (Series IV) through the transition

\begin{tabular}{|c|c|c|c|c|}
\hline$T_{1} / \mathbf{K}$ & $T_{2} / \mathrm{K}$ & $\frac{\Delta_{T_{1}^{2}}^{T_{2}} H_{\mathrm{m}}^{\circ}}{R \cdot \mathrm{K}}$ & $\frac{\Delta_{22 \mathrm{~K}}^{30 \mathrm{~K}} H_{\mathrm{m}}^{\circ}}{R \cdot \mathrm{K}}$ & $\frac{\Delta_{22 \mathrm{~K}}^{30 \mathrm{~K}} S_{\mathrm{m}}^{\circ}}{R}$ \\
\hline $\begin{array}{l}\quad 21.505 \\
\text { Graphical integration } \\
\text { Lattice contribution } \\
\Delta_{\mathrm{trs}} H_{\mathrm{m}}^{\circ} /(R \cdot \mathrm{K}) \text { : } \\
\Delta_{\mathrm{trs}} S_{\mathrm{m}}^{\circ} / R\end{array}$ & 33.793 & 101.5 & $\begin{array}{l}73.67 \pm 0.05 \\
73.63 \pm 0.05^{a} \\
40.69 \pm 0.05^{a} \\
32.98 \pm 0.10\end{array}$ & $\begin{array}{l}2.773 \pm 0.002 \\
1.557 \pm 0.002 \\
1.216 \pm 0.004\end{array}$ \\
\hline
\end{tabular}

${ }^{a}$ Error due to the uncertainty in the position of the lattice-heat-capacity curve through the region of the anomaly. 


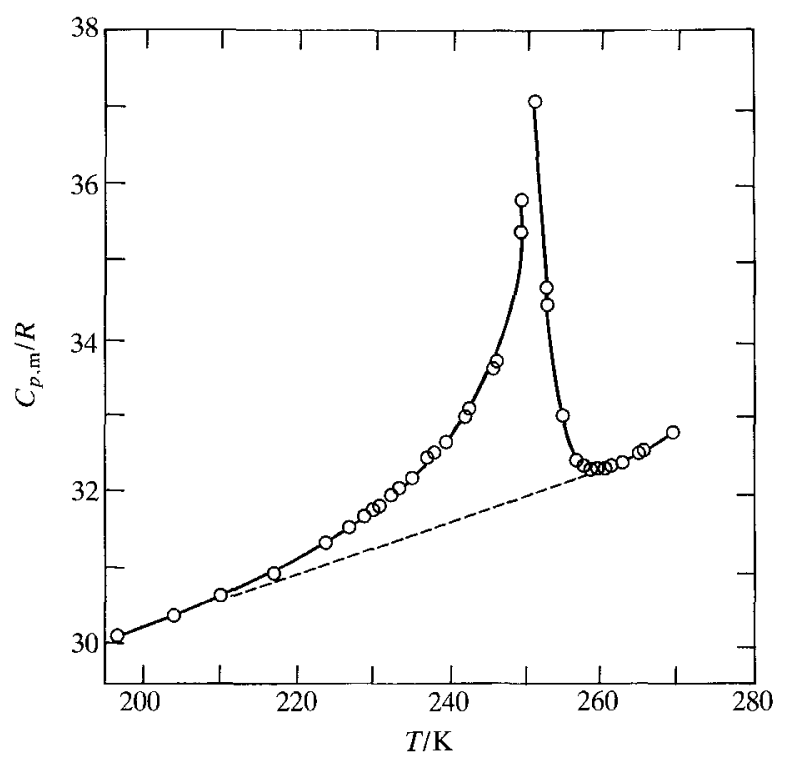

FIGURE 3. Experimental molar heat capacities $C_{n, \mathrm{~m}}$ at constant pressure plotted against temperature $T$ through the region of the transition from $200 \mathrm{~K}$ to $270 \mathrm{~K}$ due to 0.25 mass per cent of $\mathrm{ND}_{4} \mathrm{Cl}_{\text {in }}$ $\left(\mathrm{ND}_{4}\right)_{2} \mathrm{PtCl}_{6}$; - - , the lattice curve.

(Series VI to VIII) were made through this anomaly to determine the associated enthalpy. By interpolating the background heat-capacity curve from about $265 \mathrm{~K}$ to $290 \mathrm{~K}$, the excess enthalpy of $2.487 \mathrm{~J} \cdot \mathrm{mol}^{-1}$ associated with the anomaly was determined, which led to the calculation of the $\mathrm{D}_{2} \mathrm{O}$ impurity of 0.07 mass per cent. The experimental $C_{p, \mathrm{~m}} / R$ values for our $\left(\mathrm{ND}_{4}\right)_{2} \mathrm{PtCl}_{6}$ sample shown in table 1 were not adjusted for the impurity.

Integration of the smoothed values for experimental heat capacity and for the enthalpy and entropy increments through the anomalies yielded the thermodynamic functions. Values of $C_{p, \mathrm{~m}} / R$ and the derived functions are presented at selected temperatures in table 3 . The corresponding values for the lattice curve beneath the anomalies, drawn by smooth interpolation, are given in parentheses. The heat capacities of $\left(\mathrm{ND}_{4}\right)_{2} \mathrm{PtCl}_{6}$ below $5 \mathrm{~K}$ were obtained by fitting our experimental values below $20 \mathrm{~K}$ to the limiting form of the Debye equation using a plot of $C_{p, \mathrm{~m}} / T^{3}$ against $T^{2}$ and extrapolating to $T \rightarrow 0$.

The values given in table 3 and plotted in figure 4 are for the pure salt and were obtained by correcting the smoothed experimental heat capacities for the 0.07 mass per cent of $\mathrm{D}_{2} \mathrm{O}$ impurity as well as for the 0.25 mass per cent of $\mathrm{ND}_{4} \mathrm{Cl}$ impurity noted above. The heat-capacity values of $\mathrm{D}_{2} \mathrm{O}$ by Long and $\mathrm{Kemp}^{(36)}$ were used; which lowered our $C_{p, m}$ values for $\left(\mathrm{ND}_{4}\right)_{2} \mathrm{PtCl}_{6}$ by about $(0 \cdot 1$ to $0 \cdot 2)$ per cent up to $200 \mathrm{~K}$, by 0.23 per cent up to $270 \mathrm{~K}$, and by about 0.50 per cent above $278 \mathrm{~K}$. To correct our $C_{p, \mathrm{~m}} / R$ values for the 0.25 mass per cent $\mathrm{ND}_{4} \mathrm{Cl}$ impurity, the heatcapacity values of $\mathrm{NH}_{4} \mathrm{Cl}$ by Callanan, Weir, and Staveley ${ }^{(37)}$ were taken since those for $\mathrm{ND}_{4} \mathrm{Cl}$ are not tabulated by Stephenson et al. ${ }^{(35)}$ Given the small amount of 
TABLE 3. Standard molar thermodynamic functions for pure $\left(\mathrm{ND}_{4}\right)_{2} \mathrm{PtCl}_{6}\left(M=451.9334 \mathrm{~g} \cdot \mathrm{mol}^{-1}\right.$,

$$
\left.p^{\circ}=101.325 \mathrm{kPa}, R=8.31451 \mathrm{~J} \cdot \mathrm{K}^{-1} \cdot \mathrm{mol}^{-1}, \Phi_{\mathrm{m}}^{\circ} \stackrel{\text { def }}{=} \Delta_{0}^{T} S_{\mathrm{m}}^{\circ}-\Delta_{0}^{T} H_{\mathrm{m}}^{\circ} / T\right)
$$

\begin{tabular}{|c|c|c|c|c|c|c|c|c|c|}
\hline$\frac{T}{\overline{\mathrm{K}}}$ & $\frac{C_{p, \mathrm{~m}}}{R}$ & $\frac{\Delta_{0}^{T} S_{\mathrm{m}}^{\circ}}{R}$ & $\frac{\Lambda_{0}^{T} H_{\mathrm{m}}^{\circ}}{R \cdot \mathrm{K}}$ & $\frac{\Phi_{\mathrm{m}}^{\circ}}{R}$ & $\frac{T}{\mathbf{K}}$ & $\frac{C_{p, \mathrm{~m}}}{R}$ & $\frac{\Delta_{0}^{T} S_{\mathrm{m}}^{\circ}}{R}$ & $\frac{\Delta_{0}^{T} H_{\mathrm{m}}^{\circ}}{R \cdot \mathbf{K}}$ & $\frac{\Phi_{\mathrm{m}}^{\circ}}{R}$ \\
\hline 0 & 0 & 0 & 0 & 0 & 160 & 27.98 & 32.27 & 2679.5 & 15.52 \\
\hline 5 & $(0.0420)$ & $(0.0136)$ & $(0.0526)$ & $(0.0030)$ & & (27.98) & $(31.05)$ & $(2646.5)$ & $(14.51)$ \\
\hline 10 & 0.468 & 0.144 & 1.12 & 0.032 & 165 & 28.23 & 33.13 & 2820.0 & 16.04 \\
\hline 15 & 1.443 & 0.498 & 5.66 & 0.121 & & $(28.23)$ & $(31.92)$ & (2787.1) & (15.02) \\
\hline 20 & 3.021 & 1.124 & 16.74 & 0.287 & 170 & 28.55 & 33.98 & 2961.9 & 16.56 \\
\hline 21 & 3.346 & 1.279 & 19.92 & 0.331 & & (28.55) & $(32.76)$ & $(2929.0)$ & (15.53) \\
\hline 22 & 3.705 & 1.443 & 23.45 & 0.377 & 175 & 28.81 & 34.81 & 3105.3 & 17.07 \\
\hline 23 & 4.160 & 1.618 & 27.38 & 0.427 & & (28.81) & (33.59) & (3072.4) & (16.04) \\
\hline 24 & $\begin{array}{c}4.724 \\
a(4.449)\end{array}$ & $\begin{array}{c}1.806 \\
699\end{array}$ & $\begin{array}{c}31.80 \\
(31.64)\end{array}$ & $\begin{array}{c}0.481 \\
(0.481)\end{array}$ & 180 & $\begin{array}{c}29.05 \\
(29.05)\end{array}$ & $\begin{array}{c}35.63 \\
(34.41)\end{array}$ & $\begin{array}{c}3250.0 \\
(3217.0\end{array}$ & $\begin{array}{c}17.57 \\
(16.54)\end{array}$ \\
\hline 25 & $\begin{array}{c}(4.449) \\
5.500 \\
(4.784)\end{array}$ & $\begin{array}{c}(1.799) \\
2.016 \\
(1.987)\end{array}$ & $\begin{array}{c}(31.64) \\
36.95 \\
(36.25)\end{array}$ & $\begin{array}{c}(0.481) \\
0.538 \\
(0.537)\end{array}$ & 185 & $\begin{array}{c}(29.05) \\
29.30 \\
(29.30)\end{array}$ & $\begin{array}{c}(34.41) \\
36.43 \\
(35.21)\end{array}$ & $\begin{array}{c}3395.8 \\
(3362.9)\end{array}$ & $\begin{array}{c}18.0 .07 \\
(17.03)\end{array}$ \\
\hline 26 & $\begin{array}{c}7.300 \\
(5.113)\end{array}$ & $\begin{array}{c}2.266 \\
(2.181)\end{array}$ & $\begin{array}{c}43.35 \\
(41.20)\end{array}$ & $\begin{array}{c}0.599 \\
(0.597)\end{array}$ & 190 & $\begin{array}{c}29.54 \\
(29.54)\end{array}$ & $\begin{array}{c}37.21 \\
(35.99)\end{array}$ & $\begin{array}{c}3542.9 \\
(3510.0)\end{array}$ & $\begin{array}{c}18.56 \\
(17.52)\end{array}$ \\
\hline 27 & $\begin{array}{l}25.80 \\
(5.428)\end{array}$ & $\begin{array}{c}2.732 \\
(2.380)\end{array}$ & $\begin{array}{c}55.77 \\
(46.48)\end{array}$ & $\begin{array}{c}0.666 \\
(0.659)\end{array}$ & 195 & $\begin{array}{c}29.77 \\
(29.77)\end{array}$ & $\begin{array}{c}37.98 \\
(36.76)\end{array}$ & $\begin{array}{c}3691.1 \\
(3658.2)\end{array}$ & $\begin{array}{c}19.05 \\
(18.00)\end{array}$ \\
\hline 28 & $\begin{array}{c}9.200 \\
(5.737)\end{array}$ & $\begin{array}{c}3.763 \\
(2.583)\end{array}$ & $\begin{array}{c}83.96 \\
(52.08)\end{array}$ & $\begin{array}{c}0.764 \\
(0.724)\end{array}$ & 200 & $\begin{array}{c}29.99 \\
(29.99)\end{array}$ & $\begin{array}{c}38.74 \\
(37.52)\end{array}$ & $\begin{array}{c}3840.5 \\
(3807.6)\end{array}$ & $\begin{array}{c}19.53 \\
(18.48)\end{array}$ \\
\hline 29 & $\begin{array}{c}6.197 \\
6.042)\end{array}$ & $\begin{array}{c}4.004 \\
(2.790)\end{array}$ & $\begin{array}{c}90.84 \\
(57.96)\end{array}$ & $\begin{array}{c}0.872 \\
(0792)\end{array}$ & 205 & $\begin{array}{c}30.14 \\
(30.14)\end{array}$ & $\begin{array}{c}39.48 \\
(38.26)\end{array}$ & $\begin{array}{c}3990.9 \\
(3957.99\end{array}$ & $\begin{array}{c}20.01 \\
(18.96\end{array}$ \\
\hline 30 & $\begin{array}{c}6.332 \\
(6.332)\end{array}$ & $\begin{array}{c}4.216 \\
(3.000)\end{array}$ & $\begin{array}{c}97.08 \\
(64.14)\end{array}$ & $\begin{array}{c}0.980 \\
(0.862)\end{array}$ & 210 & $\begin{array}{c}30.32 \\
(30.32)\end{array}$ & $\begin{array}{c}40.21 \\
(38.99)\end{array}$ & $\begin{array}{c}4142.0 \\
(4109.1)\end{array}$ & $\begin{array}{c}20.48 \\
(19.42)\end{array}$ \\
\hline 35 & $\begin{array}{c}7.654 \\
(7.654)\end{array}$ & $\begin{array}{c}5.290 \\
(4.074)\end{array}$ & $\begin{array}{l}132.0 \\
(99.11)\end{array}$ & $\begin{array}{c}1.518 \\
(1.243)\end{array}$ & 215 & $\begin{array}{c}30.49 \\
(30.49)\end{array}$ & $\begin{array}{c}40.92 \\
(39.71)\end{array}$ & $\begin{array}{c}4294.0 \\
(4261.1)\end{array}$ & $\begin{array}{c}20.95 \\
(19.89)\end{array}$ \\
\hline 40 & $\begin{array}{c}9.023 \\
(9.023)\end{array}$ & $\begin{array}{c}6.401 \\
(5.185)\end{array}$ & $\begin{array}{c}173.7 \\
(140.8)\end{array}$ & $\begin{array}{r}2.057 \\
(1.665)\end{array}$ & 220 & $\begin{array}{c}30.67 \\
(30.67)\end{array}$ & $\begin{array}{c}41.62 \\
(40.41)\end{array}$ & $\begin{array}{c}4446.9 \\
(4414.0)\end{array}$ & $\begin{array}{c}21.41 \\
(20.35)\end{array}$ \\
\hline 45 & $\begin{array}{c}10.41 \\
(10.41)\end{array}$ & $\begin{array}{c}7.543 \\
(6.327)\end{array}$ & $\begin{array}{c}222.3 \\
(189.4)\end{array}$ & $\begin{array}{c}2.603 \\
(2.119)\end{array}$ & 225 & $\begin{array}{c}30.85 \\
(30.85)\end{array}$ & $\begin{array}{c}42.32 \\
(41.10)\end{array}$ & $\begin{array}{c}4600.8 \\
(4567.7)\end{array}$ & $\begin{array}{c}21.87 \\
(20.80)\end{array}$ \\
\hline 50 & $\begin{array}{c}11.71 \\
(11.71)\end{array}$ & $\begin{array}{c}8.706 \\
(7.490)\end{array}$ & $\begin{array}{c}277.6 \\
(244.7)\end{array}$ & $\begin{array}{c}3.155 \\
(2.597)\end{array}$ & 230 & $\begin{array}{c}31.04 \\
(31.04)\end{array}$ & $\begin{array}{c}43.00 \\
(41.78)\end{array}$ & $\begin{array}{c}4755.4 \\
(4722.5)\end{array}$ & $\begin{array}{c}22.32 \\
(21.25)\end{array}$ \\
\hline 55 & $\begin{array}{c}13.04 \\
(13.04)\end{array}$ & $\begin{array}{c}9.884 \\
(8.668)\end{array}$ & $\begin{array}{c}339.5 \\
(306.5)\end{array}$ & $\begin{array}{c}3.712 \\
(3.095)\end{array}$ & 235 & $\begin{array}{c}31.23 \\
(31.23)\end{array}$ & $\begin{array}{c}43.67 \\
(42.45)\end{array}$ & $\begin{array}{c}4911.1 \\
(4878.1)\end{array}$ & $\begin{array}{c}22.77 \\
(21.69)\end{array}$ \\
\hline 60 & $\begin{array}{c}14.31 \\
(14.31)\end{array}$ & $\begin{array}{l}11.07 \\
(9.857)\end{array}$ & $\begin{array}{c}407.8 \\
(374.9)\end{array}$ & $\begin{array}{c}4.276 \\
(3.609)\end{array}$ & 240 & $\begin{array}{c}31.41 \\
(31.41)\end{array}$ & $\begin{array}{c}44.33 \\
(43.11)\end{array}$ & $\begin{array}{r}5067.6 \\
(5034.7)\end{array}$ & $\begin{array}{c}23.21 \\
(22.13)\end{array}$ \\
\hline 65 & $\begin{array}{c}15.55 \\
(15.55)\end{array}$ & $\begin{array}{l}12.27 \\
(11.05)\end{array}$ & $\begin{array}{c}482.4 \\
(449.5)\end{array}$ & $\begin{array}{c}4.845 \\
(4.136)\end{array}$ & 245 & $\begin{array}{c}31.58 \\
(31.58)\end{array}$ & $\begin{array}{c}44.97 \\
(43.76)\end{array}$ & $\begin{array}{c}5225.1 \\
(5192.2)\end{array}$ & $\begin{array}{c}23.65 \\
(22.57)\end{array}$ \\
\hline 70 & $\begin{array}{c}16.69 \\
(16.69)\end{array}$ & $\begin{array}{c}13.46 \\
(12.25)\end{array}$ & $\begin{array}{c}563.1 \\
(530.2)\end{array}$ & $\begin{array}{c}5.418 \\
(4.672)\end{array}$ & 250 & $\begin{array}{c}31.76 \\
(31.76)\end{array}$ & $\begin{array}{c}45.61 \\
(44.40)\end{array}$ & $\begin{array}{c}5383.4 \\
(5350.5)\end{array}$ & $\begin{array}{c}24.08 \\
(23.00)\end{array}$ \\
\hline 75 & $\begin{array}{c}17.75 \\
(17.75)\end{array}$ & $\begin{array}{c}14.65 \\
(13.43)\end{array}$ & $\begin{array}{c}649.2 \\
(616.3)\end{array}$ & $\begin{array}{c}5.994 \\
(5.217)\end{array}$ & 255 & $\begin{array}{c}31.93 \\
(31.93)\end{array}$ & $\begin{array}{c}46.24 \\
(45.03)\end{array}$ & $\begin{array}{c}5542.6 \\
(5509.7)\end{array}$ & $\begin{array}{c}24.51 \\
(23.42)\end{array}$ \\
\hline 80 & $\begin{array}{c}18.79 \\
(18.79)\end{array}$ & $\begin{array}{c}15.83 \\
(14.61)\end{array}$ & $\begin{array}{c}740.6 \\
(707.6)\end{array}$ & $\begin{array}{c}6.572 \\
(5.767)\end{array}$ & 260 & $\begin{array}{c}32.09 \\
(32.09)\end{array}$ & $\begin{array}{c}46.87 \\
(45.65)\end{array}$ & $\begin{array}{c}5702.7 \\
(5689.7)\end{array}$ & $\begin{array}{c}24.93 \\
(23.84)\end{array}$ \\
\hline 85 & $\begin{array}{c}19.73 \\
(19.73)\end{array}$ & $\begin{array}{c}17.00 \\
(15.78)\end{array}$ & $\begin{array}{c}836.9 \\
(804.0)\end{array}$ & $\begin{array}{c}7.151 \\
(6.322)\end{array}$ & 265 & $\begin{array}{c}32.24 \\
(32.24)\end{array}$ & $\begin{array}{c}47.48 \\
(46.26)\end{array}$ & $\begin{array}{r}5853.5 \\
(5830.6)\end{array}$ & $\begin{array}{c}25.35 \\
(24.26)\end{array}$ \\
\hline 90 & $\begin{array}{c}20.62 \\
(20.62)\end{array}$ & $\begin{array}{c}18.15 \\
(16.93)\end{array}$ & $\begin{array}{c}937.8 \\
(904.8)\end{array}$ & $\begin{array}{c}7.730 \\
(6.880)\end{array}$ & 270 & $\begin{array}{c}32.38 \\
(32.38)\end{array}$ & $\begin{array}{c}48.08 \\
(46.87)\end{array}$ & $\begin{array}{c}6025.0 \\
(5992.1)\end{array}$ & $\begin{array}{c}25.77 \\
(24.67)\end{array}$ \\
\hline 95 & $\begin{array}{c}21.44 \\
(21.44)\end{array}$ & $\begin{array}{c}19.29 \\
(18.07)\end{array}$ & $\begin{array}{c}1042.9 \\
(1010.0)\end{array}$ & $\begin{array}{c}8.308 \\
(7.439)\end{array}$ & 275 & $\begin{array}{c}32.52 \\
(32.52)\end{array}$ & $\begin{array}{c}48.68 \\
(47.46)\end{array}$ & $\begin{array}{c}6187.3 \\
(6154.3)\end{array}$ & $\begin{array}{c}26.18 \\
(25.08)\end{array}$ \\
\hline 100 & $\begin{array}{c}22.20 \\
(22.20)\end{array}$ & $\begin{array}{c}20.41 \\
(19.19)\end{array}$ & $\begin{array}{c}1152.0 \\
(1118.1)\end{array}$ & $\begin{array}{c}8.885 \\
(7.999)\end{array}$ & 280 & $\begin{array}{c}32.66 \\
(32.66)\end{array}$ & $\begin{array}{c}49.27 \\
(48.05)\end{array}$ & $\begin{array}{c}6350.2 \\
(6317.3)\end{array}$ & $\begin{array}{c}26.59 \\
(25.49)\end{array}$ \\
\hline 105 & $\begin{array}{c}22.88 \\
(22.88)\end{array}$ & $\begin{array}{c}21.51 \\
(20.29)\end{array}$ & $\begin{array}{c}1264.7 \\
(1231.8)\end{array}$ & $\begin{array}{c}9.460 \\
(8.558)\end{array}$ & 285 & $\begin{array}{c}32.79 \\
(32.79)\end{array}$ & $\begin{array}{c}49.84 \\
(48.63)\end{array}$ & $\begin{array}{c}6513.8 \\
(6480.9)\end{array}$ & $\begin{array}{c}26.99 \\
(25.89)\end{array}$ \\
\hline
\end{tabular}


TABLE 3-continued

\begin{tabular}{|c|c|c|c|c|c|c|c|c|c|}
\hline$\frac{T}{\overline{\mathrm{K}}}$ & $\frac{C_{p, \mathrm{~m}}}{R}$ & $\frac{\Delta_{0}^{T} S_{\mathrm{m}}^{\circ}}{R}$ & $\frac{\Delta_{0}^{T} H_{\mathrm{m}}^{\circ}}{R \cdot \overline{\mathbf{K}}}$ & $\frac{\Phi_{\mathrm{m}}^{\bullet}}{R}$ & $\frac{T}{\mathrm{~K}}$ & $\frac{C_{p, m}}{R}$ & $\frac{\Delta_{0}^{T} S_{\mathrm{m}}^{\circ}}{R}$ & $\frac{\Delta_{0}^{T} H_{\mathrm{m}}^{\circ}}{R \cdot \mathrm{K}}$ & $\frac{\Phi_{\mathrm{m}}^{\circ}}{R}$ \\
\hline 110 & $\begin{array}{c}23.51 \\
(23.51)\end{array}$ & $\begin{array}{c}22.58 \\
(21.37)\end{array}$ & $\begin{array}{c}1380.7 \\
(1347.8)\end{array}$ & $\begin{array}{l}10.03 \\
(9.116)\end{array}$ & 290 & $\begin{array}{c}32.93 \\
(32.93)\end{array}$ & $\begin{array}{c}50.42 \\
(49.20)\end{array}$ & $\begin{array}{c}6678.1 \\
(6645.2)\end{array}$ & $\begin{array}{c}27.39 \\
(26.29)\end{array}$ \\
\hline 115 & $\begin{array}{c}24.09 \\
(24.09)\end{array}$ & $\begin{array}{c}23.64 \\
(22.43)\end{array}$ & $\begin{array}{c}1499.7 \\
(1466.7)\end{array}$ & $\begin{array}{l}10.60 \\
(9.672)\end{array}$ & 295 & $\begin{array}{c}33.05 \\
(33.05)\end{array}$ & $\begin{array}{c}50.98 \\
(49.76)\end{array}$ & $\begin{array}{c}6843.0 \\
(6810.1)\end{array}$ & $\begin{array}{c}27.78 \\
(26.68)\end{array}$ \\
\hline 120 & $\begin{array}{c}24.64 \\
(24.64)\end{array}$ & $\begin{array}{c}24.68 \\
(23.46)\end{array}$ & $\begin{array}{c}1621.5 \\
(1588.5)\end{array}$ & $\begin{array}{c}11.17 \\
(10.23)\end{array}$ & 300 & $\begin{array}{c}33.17 \\
(33.17)\end{array}$ & $\begin{array}{c}51.54 \\
(50.32)\end{array}$ & $\begin{array}{c}7008.6 \\
(6976.7)\end{array}$ & $\begin{array}{c}28.17 \\
(27.07)\end{array}$ \\
\hline 125 & $\begin{array}{c}25.15 \\
(25.15)\end{array}$ & $\begin{array}{c}25.70 \\
(24.48)\end{array}$ & $\begin{array}{c}1746.9 \\
(1713.0)\end{array}$ & $\begin{array}{c}11.73 \\
(10.78)\end{array}$ & 310 & $\begin{array}{c}33.61 \\
(33.61)\end{array}$ & $\begin{array}{c}52.63 \\
(51.41)\end{array}$ & $\begin{array}{c}7342.5 \\
(7309.5)\end{array}$ & $\begin{array}{c}28.95 \\
(27.84)\end{array}$ \\
\hline 130 & $\begin{array}{c}25.63 \\
(25.63)\end{array}$ & $\begin{array}{c}26.69 \\
(25.48)\end{array}$ & $\begin{array}{c}1872.8 \\
(1839.9)\end{array}$ & $\begin{array}{c}12.28 \\
(11.32)\end{array}$ & 320 & $\begin{array}{c}34.05 \\
(34.05)\end{array}$ & $\begin{array}{c}53.71 \\
(52.49)\end{array}$ & $\begin{array}{c}7680.8 \\
(7647.8)\end{array}$ & $\begin{array}{c}29.70 \\
(28.59)\end{array}$ \\
\hline 135 & $\begin{array}{c}26.09 \\
(26.09)\end{array}$ & $\begin{array}{c}27.67 \\
(26.45)\end{array}$ & $\begin{array}{c}2002.1 \\
(1969.2)\end{array}$ & $\begin{array}{c}12.84 \\
(11.86)\end{array}$ & 330 & $\begin{array}{c}34.45 \\
(34.45)\end{array}$ & $\begin{array}{c}54.76 \\
(53.54)\end{array}$ & $\begin{array}{c}8023.2 \\
(7990.3)\end{array}$ & $\begin{array}{c}30.45 \\
(29.33)\end{array}$ \\
\hline 140 & $\begin{array}{c}26.54 \\
(26.54)\end{array}$ & $\begin{array}{c}28.62 \\
(27.41)\end{array}$ & $\begin{array}{c}2133.6 \\
(2100.8)\end{array}$ & $\begin{array}{c}13.38 \\
(12.40)\end{array}$ & 340 & $\begin{array}{c}34.84 \\
(34.84)\end{array}$ & $\begin{array}{c}55.79 \\
(54.58)\end{array}$ & $\begin{array}{c}8369.7 \\
(8336.7)\end{array}$ & $\begin{array}{c}31.18 \\
(30.06)\end{array}$ \\
\hline 145 & $\begin{array}{c}26.94 \\
(26.94)\end{array}$ & $\begin{array}{c}29.56 \\
(28.35)\end{array}$ & $\begin{array}{c}2267.4 \\
(2234.4)\end{array}$ & $\begin{array}{c}13.93 \\
(12.84)\end{array}$ & 350 & $\begin{array}{c}35.20 \\
(35.20)\end{array}$ & $\begin{array}{c}56.81 \\
(55.69)\end{array}$ & $\begin{array}{c}8719.8 \\
(8686.9)\end{array}$ & $\begin{array}{c}31.89 \\
(30.77)\end{array}$ \\
\hline 150 & $\begin{array}{c}27.31 \\
(27.31)\end{array}$ & $\begin{array}{c}30.48 \\
(29.27)\end{array}$ & $\begin{array}{c}2403.0 \\
(2370.0)\end{array}$ & $\begin{array}{c}14.46 \\
(13.47)\end{array}$ & 298.15 & 33.12 & 51.33 & 6947.3 & 28.03 \\
\hline 155 & $\begin{array}{c}27.66 \\
(27.66)\end{array}$ & $\begin{array}{c}31.38 \\
(30.17)\end{array}$ & $\begin{array}{c}2540.4 \\
(2507.4)\end{array}$ & $\begin{array}{c}14.99 \\
(13.99)\end{array}$ & & \pm 0.03 & \pm 0.05 & \pm 9.6 & \pm 0.03 \\
\hline
\end{tabular}

${ }^{a}$ Quantities in parentheses represent the values taken on the lattice curve.

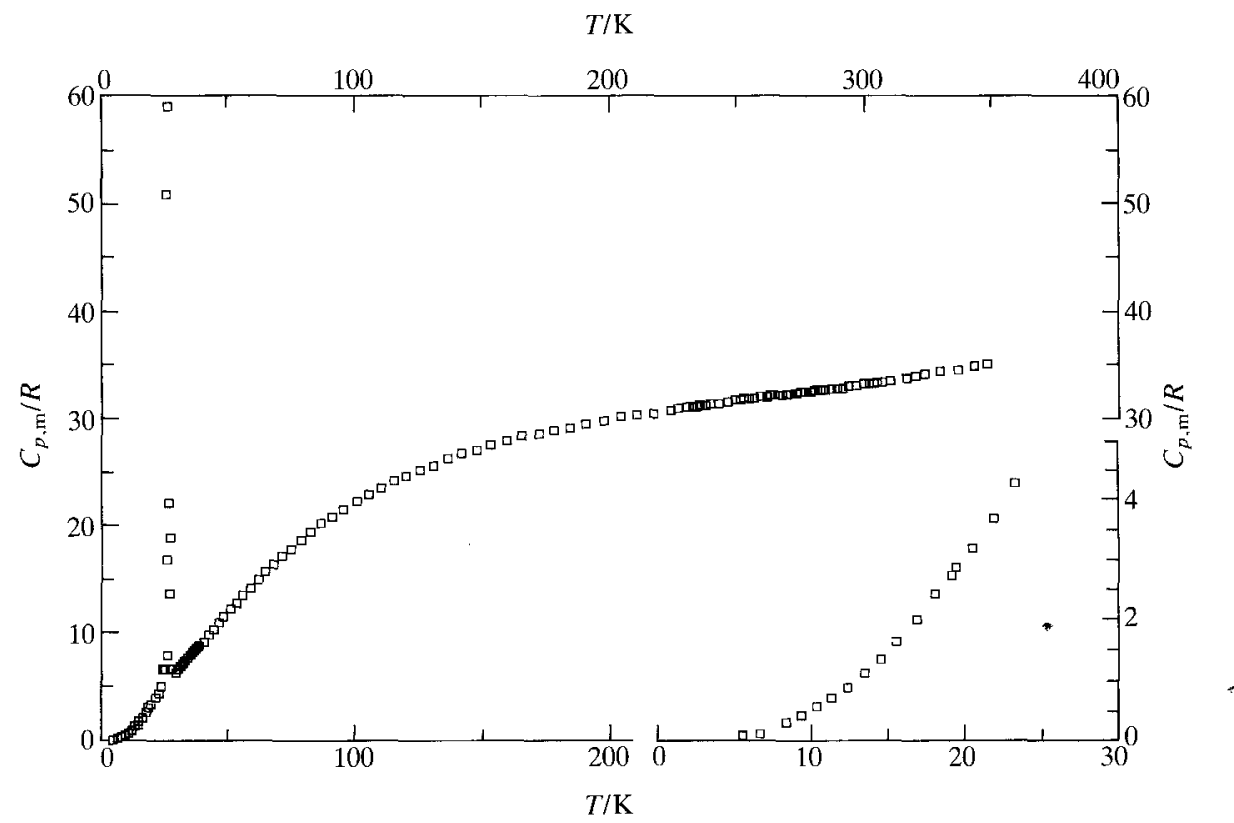

FIGURE 4. Experimental molar heat capacities $C_{p, \mathrm{~m}}$ at constant pressure plotted against temperature $T$ for pure $\left(\mathrm{ND}_{4}\right)_{2} \mathrm{PtCl}_{6}$. The region below $25 \mathrm{~K}$ is enlarged in the lower right-hand corner. 
impurity, the error introduced by this procedure is insignificant. There was a negligible correction to our $C_{p, m}$ values for $\left(\mathrm{ND}_{4}\right)_{2} \mathrm{PtCl}_{6}$ below $50 \mathrm{~K}$, but they were lowered by $(0.1$ to 0.3$)$ per cent up to $100 \mathrm{~K}$, by 0.50 per cent up to $200 \mathrm{~K}$, and by about 0.60 per cent up to $350 \mathrm{~K}$.

The plot of $C_{p, \mathrm{~m}} / T^{3}$ against $T^{2}$ used to obtain heat capacities below $5 \mathrm{~K}$ is also useful for detecting any non-vibrational contributions to the heat capacity at low temperatures. The quantity measured calorimetrically is $C_{\mathrm{sat}} \mathrm{m}$, which for these solids equals $C_{p, \mathrm{~m}}$. Moreover, the correction of $C_{p, \mathrm{~m}}$ to $C_{V, \mathrm{~m}}$, which is required for analysis of heat-capacity results, is negligible at these low temperatures. As a result, the heat capacity of our $\left(\mathrm{ND}_{4}\right)_{2} \mathrm{PtCl}_{6}$ insulator can be written as a power series.

$$
C_{p, \mathrm{~m}} \approx C_{V, \mathrm{~m}}=a T^{3}+b T^{5}+c T^{7}+\cdots .
$$

The coefficients $a, b$, and $c$ are directly related to the corresponding power series for the frequency spectrum at low frequencies. ${ }^{(38)}$ Thus as $T \rightarrow 0$, the lattice heat capacity of the solid should become equal to that of an elastic continuum and can be approximated by the Debye $T^{3}$ law:

$$
C_{V, \mathrm{~m}}=a T^{3}
$$

and

$$
\Theta_{\mathrm{D}}^{C}=\left(12 \pi^{4} L k / 5 a\right)^{1 / 3}
$$

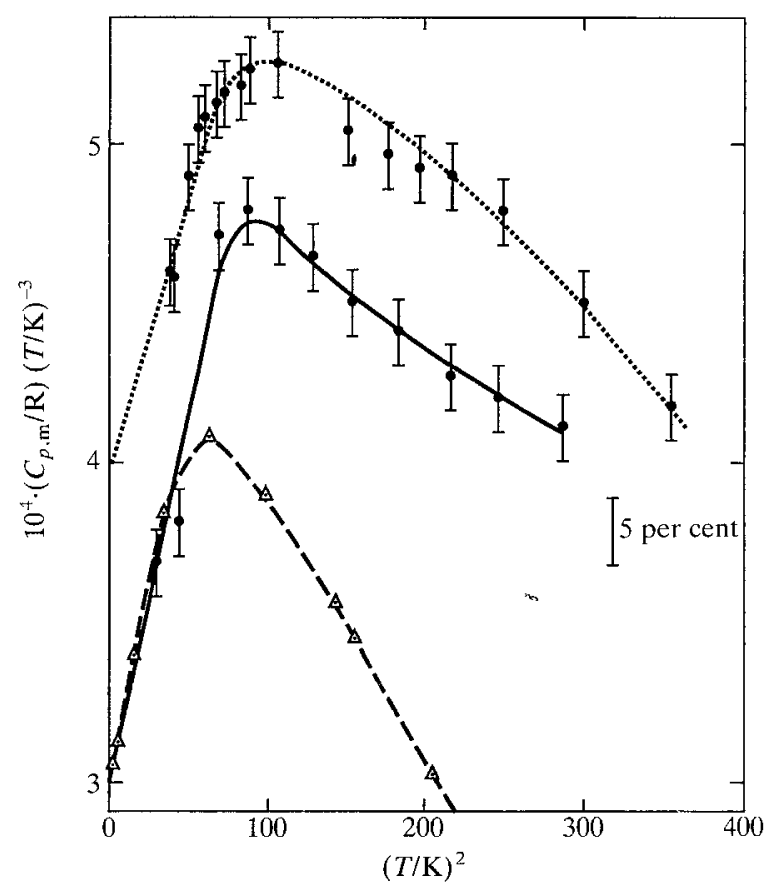

FIGURE 5. Experimental values of $C_{p, \mathrm{~m}} /\left(R T^{3}\right)$ plotted against $T^{2}$ for $\left(\mathrm{ND}_{4}\right)_{2} \mathrm{PtCl}_{6}:-$ $\cdots,\left(\mathrm{NH}_{4}\right)_{2} \mathrm{PtCl}_{2}$ (reference 21); - - , argon (references 38, 39). The vertical bars represent about 5 per cent in the $C_{p, \mathrm{~m}}$. 
The $\Theta_{D}^{C}$ is the Debye characteristic temperature derived from heat capacities. The $L$ and $k$ are, respectively, Avogadro's and Boltzmann's constants. In figure 5 for the region $36<\left(T^{2} / \mathrm{K}^{2}\right)<300$, the experimental heat capacities for $\left(\mathrm{ND}_{4}\right)_{2} \mathrm{PtCl}_{6}$ are no longer influenced by the $\lambda$-type transition near $27 \mathrm{~K}$ and follow a curve similar in shape to that for argon. ${ }^{(39,40)}$ Hence only lattice vibrations make significant contributions to the heat capacity below $17 \mathrm{~K}$. Extrapolation of the points below $T^{2}=30 \mathrm{~K}^{2}$ in figure 5 to intersect the $T^{2}=0$ axis at $a / R$ gives $10^{4} \cdot a / R=$ $(3.00 \pm 0.25) \mathrm{K}^{-3}$ or $a \cdot 10^{4}=(24.9 \pm 2.1) \mathrm{J} \cdot \mathrm{K}^{-1} \cdot \mathrm{mol}^{-1}$. This yields from equation (3) $\Theta_{\mathrm{D}}^{C}=(92.1 \pm 2.6) \mathrm{K}$ and compares with $93.3 \mathrm{~K}$ for $\operatorname{argon}^{(39)}$ and $(83.7 \pm 1.0) \mathrm{K}$ for $\left(\mathrm{NH}_{4}\right)_{2} \mathrm{PtCl}_{6} \cdot{ }^{(21)}$

The dearth of ancillary information about the spectroscopy, structure, and n.m.r. of the deuterated ammonium hexachloroplatinate handicaps a further interpretation of our heat capacities. The n.m.r. measurements ${ }^{(41)}$ on $\left(\mathrm{NH}_{4}\right)_{2} \mathrm{PtCl}_{6}$, where no phase transitions occur, show that reorientation of the $\mathrm{NH}_{4}^{+}$dominates the relaxation between $55 \mathrm{~K}$ and $250 \mathrm{~K}$ and that $\mathrm{PtCl}_{6}^{-}$reorientation begins to contribute to the relaxation above $140 \mathrm{~K}$. Whether this is also the case in $\left(\mathrm{ND}_{4}\right)_{2} \mathrm{PtCl}_{6}$ remains to be seen given the presence of the $\lambda$-shaped transition at about $27 \mathrm{~K}$ in this salt. The magnitude of the entropy change for the $\lambda$-shaped transition derived from our heatcapacity measurements suggests an order-disorder transition at $27.2 \mathrm{~K}$ with $\Delta_{\mathrm{trs}} S_{\mathrm{m}}^{\circ}=$ $(1.216 \pm 0.004) \cdot R$ (compare $\ln 3=1.099, \ln 4=1.386)$. The crystal structure needs to be determined near, but both above and below, $27.2 \mathrm{~K}$.

We thank Dr R. D. Heyding for determining the crystal structure of our sample. One of us (RDW) thanks the Department of Defence (Canada) for financial support.

\section{REFERENCES}

1. Rössler, K.; Winter, J. Chem. Phys. Lett. 1977, 46, 566.

2. Armstrong, R. L. Phys. Rep. 1980, 57, 343.

3. Brown, I. D. Can. J. Chem. 1964, 42, 2758.

4. Regelsberger, M.; Pelz, J. Solid State Comm. 1978, 28, 783.

5. O'Leary, G. P.; Wheeler, R. G. Phys. Rev. 1970, B1, 4409.

6. Lynn, J. W.; Patterson, H. H.; Shirane, G.; Wheeler, R. G. Solid State Comm. 1978, $27,859$.

7. Mintz, D.; Armstrong, R. L.; Powell, B. M.; Buyers, W. J. L. Phys. Rev. 1979, B19, 448.

8. Marignac, M. Ann. Mines 1857, 12, 19.

9. Stephenson, C. C.; Wulff, C. A.; Lundell, O. R. J. Chem. Phys. 1964, 40, 967.

10. Smith, D. Chem. Phys. Lett. 1974, 25, 348.

11. Strange, J. H.; Terenzi, M. J. Phys. Chem. Solids 1972, 33, 923.

12. Smith, D.; Weir, R. D.; Westrum, E. F., Jr. J. Chem. Thermodynamics 1990, 22, 421.

13. Morphee, R. G. S.; Staveley, L. A. K.; Walters, S. T.; Wigley, D. L. J. Phys. Chem. Solids 1960, 13, 132.

14. Svare, I. J. Phys. C: Solid State Phys. 1977, 10, 4137.

15. Prager, M.; Press, W.; Alefield, B.; Hüller, A. J. Chem. Phys. 1977, 67, 5126.

16. Svare, I.; Raaen, A. M.; Thorkildsen, G. J. Phys. C: Solid State Phys. 1978, 11, 4069.

17. Callanan, J. E.; Weir, R. D.; Westrum, E. F., Jr. J. Chem. Thermodynamics 1990, $22,149$.

18. Otnes, K.; Svare, I. J. Phys C: Solid State Phys. 1979, 12, 3899.

19. Hoser, A.; Prandl, W.; Heger, G. Proceedings ILL-IFF Workshop on Quantum Aspects of Molecular Motions in Solids. Heidemann, A.; Magerl, A.; Prager, M.; Richter, D.; Springer, T.: editors. Springer: Berlin. 1986, pp. 19-23.

20. Smith, D. J. Chem. Phys. 1985, 82, 5133.

2I. Weir, R. D.; Westrum, E. F., Jr. J. Chem. Thermodynamics 1990, 22, 1097. 
22. Swanson, H. E.; Gilfrich, N. T.; Ugrinic, G. M. Natl. Bur, Stand. (U.S.) Circ. No. 539. 1955, 5. pp. 3-4.

23. Wyckoff, R. W. G. Crystal Structures. Vol. 3. Interscience: New York. 1965, p. 342.

24. Westrum, E. F., Jr.; Furukawa, G. T.; McCullough, J. P. Experimental Thermodynamics, Vol. I. McCullough, J. P.; Scott, D. W.: editors. Butterworths: London. 1968, p. 133.

25. Stimson, H. F. J. Res. Natl. Bur. Stand. 1961, 65A, 139.

26. McCrackin, F. L.; Chang, S. S. Rev. Sci. Instrum. 1975, 46, 550.

27. Chirico, R. D.; Westrum, E. F., Jr. J. Chem. Thermodynamics 1980, 12, 311.

28. Westrum, E. F., Jr. Proceedings NATO Advanced Study Institute on Thermochemistry, Viana do Castello, Portugal. Ribeiro da Silva, M. A. V.: editor. Reidel: New York. 1984, p. 745.

29. Andrews, J. T. S.; Norton, P. A.; Westrum, E. F., Jr. J. Chem. Thermodynamics 1978, 10, 949.

30. Staveley, L. A. K.; Grey, N. R.; Layzell, M. J. Z. Naturforsch. 1963, 18A, 148.

31. Morphee, R. G. S.; Staveley, L. A. K. Nature 1957, 180, 1246.

32. Miller, G. R.; Gutowsky, H. S. J. Chem. Phys. 1963, 39, 1983.

33. Parsonage, N. G.; Staveley, L. A. K. Disorder in Crystals. Clarendon: Oxford. 1978, p. 312.

34. Levy, H. A.; Peterson, S. W. Phys. Rev. 1952, 86, 766.

35. Stephenson, C. C.; Blue, R. W.; Stout, J. W. J. Chem. Phys. 1952, $20,1046$.

36. Long, E. A.; Kemp, J. D. J. Am. Chem. Soc. 1936, 58, 1829.

37. Callanan, J. E.; Weir, R. D.; Staveley, L. A. K. Proc. Roy. Soc. London 1980, A372, 497.

38. Barron, T. H. K.; Berg, W. T.; Morrison, J. A. Proc. Roy. Soc. London 1957, A242, 478.

39. Beaumont, R. H.; Chihara, H.; Morrison, J. A. Proc. Phys. Soc. London 1961, 78, 1462.

40. Finegold, L.; Phillips, N. E. Phys. Rev. 1969, 177, 1383.

41. Bonari, M.; Terenzi, M. Chem. Phys. Lett. 1974, 27, 281. 